\title{
Alberto Marsicano
}

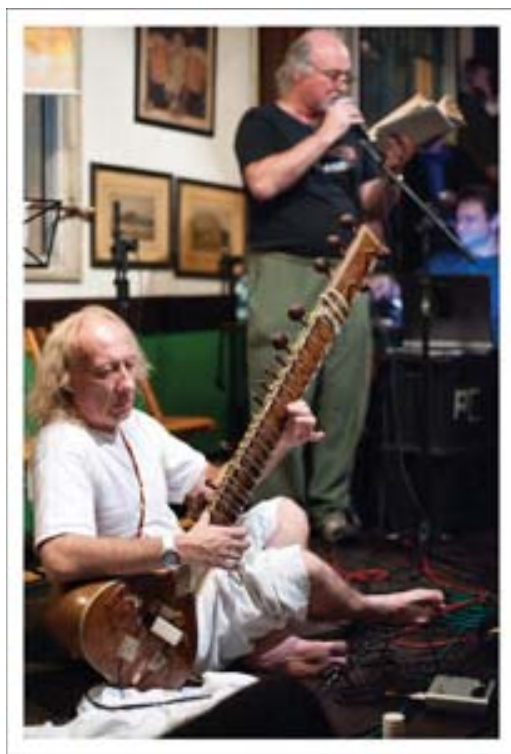

"Alberto Marsicano Rodrigues [31 de janeiro de 1952 - 18 de agosto de 2013]. Foto de Marcelo Tápia"

Conheci Alberto Marsicano no mês de maio de 1989. Estávamos ensaiando a peça curta de W. B. Yeats, "At the Hawk's Well”, para apresentar no Bloomsday no mês seguinte. Se bem me lembro, estava com Deusa, agora minha colega na USP, e José Garcez Ghirardi, professor da Fundação Getúlio Vargas. Depois do ensaio dei carona para eles no meu velho Ford Corcel, e Marsicano começou a falar sobre um funeral irlandês em Londres, para o qual ele tinha sido convidado. Colocaram o cadáver numa poltrona, lhe deram um pint de Guiness, e depois o pegaram para dançar. Foi um verdadeiro wake irlandês!

Comecei a conhecer Marsicano melhor. Suas histórias eram incríveis. Como aquela quando ele foi preso no Marrocos, suspeito de ser espião espanhol por ter fotografado aviões militares. A polícia se recusava a acreditar que ele era brasileiro, como não há loiros no Brasil. Foi logo depois do Brasil vencer a Copa de 1970. "Se 
você é realmente brasileiro, você vai poder nomear todos os jogadores da seleção brasileira que ganhou a Copa", lhe disseram. Marsicano pensou: "Félix, Brito, Piazza, Carlos Alberto, Everaldo, Clodoaldo, Gérson, Tostão, Pelé, e Rivellino". Dez. Mas quem era o décimo primeiro? Tentou negociar com o delegado, mas um verdadeiro brasileiro tinha de saber os nomes do time inteiro. Dez anos de cadeia por espionagem... E a luz veio: "Jairzinho!" E foi solto imediatamente.

As noites em Londres, quando ele via aparições de William Blake; a viagem de barco no Ganges na companhia de um "irmão" carioca que tirava sarro de tudo, até da pira sagrada num barco que passava - o carioca viu um hindu sorridente no meio de parentes que choravam e disse que a cremação só podia ser da sogra deste - quando os enlutados viram os dois gritando e dando gargalhadas tentaram linchá-los; os contatos com a máfia coreana de São Paulo; e a noite quando, em novembro de 1978, depois de um churrasco num sítio de um casal de austríacos em Caieiras, perto de São Paulo, todos os convidados tiveram de dormir no local devido às fortes chuvas. A única cama disponível era no quarto do simpático velho jardineiro alemão, Seu Peter, que sabia tudo sobre plantas e medicina. Durante a noite, Seu Peter parecia ter algum tipo de pesadelo e ataque - gritava em alemão, tremia, suava, torcia as mãos. Marsicano teve certo medo e pouco dormiu. No dia seguinte amanheceu com sol, e todos voltaram a São Paulo. Poucos meses depois, em 7 de fevereiro de 1979, o oficial médico chefe da principal enfermaria do campo de concentração de Birkenau-Auschwitz, Josef Mengele, morreu afogado na praia de Bertioga, no litoral sul de São Paulo. Marsicano viu as fotos nos jornais. Josef Mengele era Seu Peter.

Eu adorava tomar uma cerveja com Marsicano e escutar suas experiências mirabolantes. Ele não está mais conosco, mas sua wit de raconteur pode ser vista nas Crônicas Marsicanas (L\&PM 2007) e também na entrevista que ele deu ao programa da TV Cultura, Provocações, em $2012^{1}$.

Marsicano graduou-se em Filosofia pela USP e em Música Clássica pela Benares Hindu University da Índia. Aprendeu a tocar sitar com o maestro indiano Ravi Shankar em Londres. Em Benares, na Índia, estudou música clássica indiana com Krishna Chakravarty, professora da Universidade de Benares. De volta a São Paulo, acompanhou as leituras de Haroldo Campos, e misturou a cítara com música popular tradicional brasileira em Raga do Cerrado (Mcd World Music 2001), e com rock em Sitar Hendrix (Sonic Wave Internacional 2009).

1 http://www.youtube.com/watch?v=11CsfZ3e6YY 
Escreveu, entre outros, Rimbaud por Ele Mesmo (Martin Claret, 1996); Jim Morrison por Ele Mesmo (Martin Claret, 2005); e A Música Clássica da Índia (Perspectiva, 2011).

Traduziu O Casamento do Cén e do Inferno \& Outros Escritos, de William Blake (L\&PM Pocket, 2007); Conversas Com Gaudi, de Cesar Martinelli Brunet (Perspectiva, 2007); Haikai - Antologia da Poesia Clássica Japonesa (Oriento, 1988); Trilha Estreita ao Confim, de Bashô (Iluminuras, 1997) e, junto com Im Yum Jung, Sijo Poesiacanto Coreana Clássica (Iluminuras, 1994). Sua mente rápida e telegráfica (ele foi a única pessoa que conheci que assistia a filmes em fast-forward.) se deleitava com as imagens instantâneas e sintéticas da poesia oriental.

Juntos traduzimos Nas Invisiveis Asas da Poesia, uma seleção de John Keats (Iluminuras, 1998); O Olho Imóvel pela Força da Harmonia, antologia da poesia de William Wordsworth (Ateliê, 2007); e Sementes Aladas: Antologia Poética de Percy Bysshe Shelley (Ateliê, 2010).

Algumas de nossas traduções da poesia de Keats foram publicadas na Cadernos de Literatura em Tradução no. 1 (1997). Na Cadernos no. 5 (2003) saíram traduções suas de poesia arábico-andaluza. Este número contém três traduções dos poemas "Bebendo só ao luar" e "Diálogo no monte", ambos de Li Bai, que Marsicano elaborou em conjunto com Chiu Si-Yuan e Chiu Yi Chih.

Foi sempre muito fácil trabalhar com Marsicano. Eu chegava na casa dele às $20 \mathrm{~h} 00$, nas segundas-feiras. Fazia umas traduções literais orais dos poemas. Ele escrevia e "poetizava". Para a semana seguinte burilava, e chegávamos ao resultado final. Depois, muitas vezes íamos ao bar Lone Star para tomar cerveja.

Outras memórias de Marsicano: no dia das mães de 1994, vi na Folha de São Paulo ${ }^{2}$ uma foto de um sorridente Marsicano junto com a mãe, como exemplo de filho que voltou para casa da mãe, um Geraldão que adorava ser Geraldão! E quase dez anos depois, no auge dos reality shows, a Casa das Rosas colocou dez artistas em gaiolas para que o público passasse por lá e assistisse a seus ensaios e performances improvisadas. Marsicano era um deles.

E claro, todo ano, no Bloomsday, 16 de junho, apresentávamos o finale, eu lendo do Ulysses ou do Finnegans Wake, e Marsicano fazendo suas improvisações da música de Jimi Hendrix, John Coltrane, The Who, ou Led Zepellin.

Ele morreu no dia 18 de agosto de 2013. Alguns dias antes ele teve um forte ataque de asma; foi internado no Hospital São Luiz, entrou em coma, para nunca mais sair.

2 http://www1.folha.uol.com.br/fsp/1994/5/01/cotidiano/8.html 
A última brincadeira de Marsicano foi a de tirar dez anos de sua idade. O poeta Cláudio Willer, seu amigo, ao homenagear Marsicano na noite em que ele faleceu [quando Marsicano ia participar da Hora $\mathrm{H}$, homenagem ao Haroldo de Campos], se surpreendeu com o fato de que ele só tinha 51 anos: "Então ele começou a escrever muito cedo", disse Willer, um pouco confuso...

"Ergo a taça e brindo a lua: Com ela e a minha sombra, somos ${ }^{3}$... quatro?".

"Flores fuem pela corrente. Há outro mundo além do horizonte ${ }^{4}$."

John Milton

Outubro/2013

3 Versos de sua tradução de "Bebendo só ao luar", p. 174 desta edição.

4 Versos de sua tradução de "Diálogo no monte", p. 177 desta edição. 